\title{
Wastewater of Table Olive Industry and its Pollution Effects
}

\author{
Yasin Ozdemir*1 and Ozge Keskinel ${ }^{2}$ \\ ${ }^{1}$ Ataturk Horticultural Central Research Institute, Food Technologies Department, Ankara, Turkey \\ ${ }^{2}$ Ankara University, Food Engineering Department, Ankara, Turkey
}

Received: 制: October 24, 2018; Published: 橎: October 31, 2018

*Corresponding author: Yasin Ozdemir, Ataturk Horticultural Central Research Institute, Food Technologies Department, Yalova, Turkey

\begin{abstract}
Table olive industry wastewaters constitute a critical environmental pollution problem. But there was limited number of project and study on treatment and reduction of this wastewater. So that this review was focused on produced amount and pollutant effect and content of this wastewater to attract the attention of environmentally conscious producers and consumers.
\end{abstract}

\section{Introduction}

Table olive industry (TOI) wastewaters constitute a critical environmental problem in Mediterranean countries, due to its elevated contaminant levels and to its seasonal nature [1]. Usually, this wastewater is disposed into the environment untreated, leading to the possibility of the pollution of surface waters and aquifers
[2]. Olive oil is in the medina due to the pollutant property of wastewater, but the wastewater of the TOI is overlooked. Similarly, although there are many studies and projects on olive wastewater, there are few studies about table olives wastewater. So that this review was aimed to give brief information about wastewater generated by TOI and its pollutant properties (Table 1).

Table 1: Wastewaters from different table olive processing methods and plants.

\begin{tabular}{|c|c|c|c|c|c|c|c|}
\hline \multirow{2}{*}{ Characteristics } & \multicolumn{3}{|c|}{ Spanish-Style Green Olives ${ }^{a}$} & \multirow{2}{*}{ Black Olives $^{b}$} & \multirow{2}{*}{$\begin{array}{c}\text { Spanish-Style Pickled } \\
\text { Green Olive }^{c}\end{array}$} & \multirow{2}{*}{ Natural Olives $^{d}$} & \multirow{2}{*}{$\begin{array}{l}\text { Commercial Table } \\
\text { Olive Plants }\end{array}$} \\
\hline & Lye & Washing & Fermentation & & & & \\
\hline $\operatorname{COD}(\mathrm{g} / \mathrm{l})$ & 9.3 & 13.6 & 18.9 & $6.7-40$ & $15-35$ & - & $2.5-3.2$ \\
\hline $\mathrm{BOD}_{5}(\mathrm{~g} / \mathrm{l})$ & 3.11 & 4.64 & 6.05 & 4.3 & - & $34.8-38.3$ & - \\
\hline $\mathrm{pH}$ & 12.99 & 11.52 & 4.3 & $4.5-13.6$ & $9,5-12$ & $3.6-4.4$ & $5.9-6.5$ \\
\hline Total phenols (mg/l) & 80.39 & 117.23 & 76.41 & $112-360$ & $25-40$ & $3.2-5.1$ & $73-93$ \\
\hline Organic acids (mg/l) & 27.38 & 27.2 & 157.23 & - & $20-35$ & - & $117-157$ \\
\hline
\end{tabular}

Note: a: [3], b: [4,5], c: [6], d: [7], e: [8]

\section{Amount and Characteristics of Table Olives Industry Wastewaters}

World table olive production was about 2.5 million tons in the $2014 / 2015$ season, according to recent International Olive Oil Council (IOOC) statistics [9]. The main commercial types of table olives are the Spanish-style green olives ( $\sim 50 \%$ of total production), Californian-style black ripe olives ( $\sim 25 \%$ of total production), and naturally black olives in brine ( $\sim 25 \%$ of total production) [10], the manufacturing of which generates considerable quantities of different types of wastes $[3,10]$. Wastewaters from different table olive processing methods were given in (Table 1). Californian-style black-ripe olives has the highest pollutant potential with around 2-6 L/kg olives produced [11], followed by the Californian green ripe olives and Spanish table olives with an average of 1.5-3.5 $\mathrm{L} / \mathrm{kg}$ olives produced and finally, the Naturally black olives and the untreated green and turning color olives with $1 \mathrm{~L} / \mathrm{kg}$ olives produced [12,13]. Lye treatment followed by exhaustive washings for the elimination of lye had the most polluting effluents [11].

\section{Conclusion}

Currently used methods in TOI based on water, lye and salt which was the main responsible of the environmental pollution problem. From environmental perspective, it is understood that 
the eco- friendly production methods to be developed for TOI has vital importance because of the high amount and polluting nature of wastewater are produced from this industry. Due to high $\mathrm{pH}$, salt and phenol content it was difficult to treat. Also, the future market researches should be focus on determination of purchase behavior of consumers to the table olive product produced by eco-friendly techniques. Positive results of consumer purchase behavior will motivate TOI to develop and use eco- friendly production methods. Policy makers should carry out more stringent audits to ensure environmental safety and to encourage with supports producers to produce with eco-friendly methods.

\section{References}

1. Rincon Llorente B, De la Lama Calvente D, Fernández Rodríguez MJ, Borja Padilla R (2018) Table olive wastewater: problem, treatments and future strategy. A review Frontiers in microbiology 9: 1641.

2. Ayed L, Asses N, Chammem N, Othman NB, Hamdi M (2017) Advanced oxidation process and biological treatments for table olive processing wastewaters: constraints and a novel approach to integrated recycling process: a review Biodegradation 28(2-3): 125-138.

3. International Olive Oil Council (IOOC) (2015) Statistic of table olive's world production.

4. Fendri IM, Chamkha M, Bouaziz M, Labat S, Sayadi S (2013) Olive fermentation brine: biotechnological potentialities and valorization. Environ Technol 34(1-4): 181-193

5. Parinos CS, Stalikas CD, Giannopoulos TS, Pilidis GA (2007) Chemical and physicochemical profile of wastewaters produced from the different stages of Spanish-style green olives processing. Journal of hazardous materials 145(1-2): 339-343.

6. Papadaki E , Mantzouridou FT (2016) Current status and future challenges of table olive processing wastewater valorization. Biochemical engineering journal 112: 103-113.

7. Moussavi G, Barikbin B, Mahmoudi M (2010) The removal of high concentrations of phenol from saline wastewater using aerobic granular SBR. Chem Eng J 158: 498-504.

8. Ferrer Polonio E, García Quijano NT, Mendoza Roca JA, Iborr Clar A, Pastor Alcañiz L (2016) Effect of alternating anaerobic and aerobic phases on the performance of an SBR treating effluents with high salinity and phenols concentration. Biochem Eng J 113: 57-65.

9. Beltran Heredia J, Torregrosa J, Dominguez JR, Garcia J (2000) Treatment of black-olive wastewaters by ozonation and aerobic biological degradation. Water Research 34(14): 154-161.

10. Chatzisymeon E, Stypas E, Bousios S, Xekoukoulotakis NP, Mantzavinos D (2008) Photocatalytic treatment of black table olive processing wastewater. Journal of Hazardous Materials 154(1-3): 1090-1097.

11. Garrido Fernàndez A \& Fernàndez Diez MJ (1997) Table olives, production and processing.

12. Cappelletti GM, Nicoletti GM and Russo C (2011) Wastewaters from table olive industries. In: Wastewater-Evaluation and Management. (Eds.). F Sebastian and G Einschlag pp. 351-376.

13. Brenes M, García P, Romero C, Garrido A (2000) Treatment of green table olive waste waters by an activated-sludge process. Journal of Chemical Technology \& Biotechnology 75(6): 459-463.

$\begin{array}{ll}\text { BIOMEDICAL } & \text { Assets of Publishing with us } \\ \text { RESEARCHES } & \text { - Global archiving of articles } \\ \text { - Immediate, unrestricted online access }\end{array}$

ISSN: 2574-1241

DOI: 10.26717/BJSTR.2018.10.001986

Yasin Ozdemir. Biomed J Sci \& Tech Res

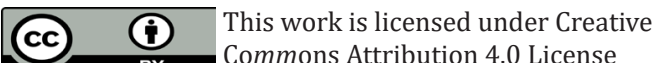

Submission Link: https://biomedres.us/submit-manuscript.php 